\title{
Frequency changes in storage protein genes in a hybrid bulk population of barley
}

\author{
K. M. IBRAHIM†, J. B. R. HAYTER $\ddagger$, J. A. BARRETT* \\ Department of Genetics, University of Cambridge, Downing Street, Cambridge CB2 3EH, U.K.
}

\begin{abstract}
Changes of frequency at three hordein loci were investigated in Composite Cross Five (CCV) of barley using SDS-PAGE of endosperm proteins. The frequency of individual banding patterns, as well as pattern combinations, showed directional trends in successive generations. This suggests that selection has favoured certain allelic combinations at two hordein loci, Hor 1 and Hor 2 . We argue that the selective advantage of resistance to powdery mildew, the inbreeding nature of barley, and linkage between some major mildew resistance genes and the hordein loci could have led to the observed shifts.
\end{abstract}

Keywords: barley, composite cross, hordein, powdery mildew, selection.

\section{Introduction}

Biochemical markers, especially allozymes, have been extensively studied in various composite cross populations of barley and used to demonstrate the effects of natural selection (Allard et al., 1972; Edwards, 1975; Clegg et al., 1978), the hitchhiking of neutral alleles with genes that are targets of selection (Luckett, 1982; Luckett \& Edwards, 1986), the multilocus structure of populations of predominantly inbreeding species (Weir et al., 1972, 1974), as well as for quantifying genetic diversity (Brown, 1978; Knight, 1991) and estimating levels of outcrossing in barley (Kahler et al., 1975; Luckett, 1982; see also Allard, 1988).

The $\mathrm{B}$ hordeins are encoded by a single structural gene, Hor2, located on the short arm of chromosome 5, 7-8 cM distal to the Horl gene which codes for the C hordeins (Jensen et al., 1980; Shewry et al., 1981). The Hor3 locus which encodes the D hordeins is located on the long arm of chromosome 5 (Shewry et al., 1983). The estimated map distance between Hor 1 and Hor 3 is $65 \mathrm{cM}$ and the gene order is Hor2-Hor1-Hor3 (Shewry et al., 1984).

Hordein fractions separated from a range of cultivars using SDS-PAGE show extensive variation in the banding pattern of polypeptides within each of the $\mathrm{B}$ and $\mathrm{C}$ hordein groups. In contrast, the D

\footnotetext{
*Correspondence.

Present addresses: †University of East Anglia, School of Biological Sciences, Norwich NR4 7TJ, U.K. and \$National Institute of Agricultural Botany, Huntingdon Road, Cambridge CB3 0LE, U.K.
}

hordein of European cultivars of barley consists of a single component polypeptide, but two components have been reported in other cultivars (Field et al., 1982; Shewry et al., 1982). The polypeptide banding patterns of $\mathrm{B}$ and $\mathrm{C}$ hordeins have been used as markers for varietal identification (Shewry et al., 1978a; Doll \& Brown, 1979). Because Horl and Hor2 are closely linked to loci for mildew (Mla, Mlat, MlGa, Mlk, Mlnn and Mlra) and yellow rust (Yr4) resistances, a number of hordein patterns in European cultivars of barley are associated with specific resistance alleles (Shewry et al., 1981; Jensen et al., 1980; Kreis et al., 1985; Jørgensen, 1994).

In a previous study (Ibrahim \& Barrett, 1991), we showed that three subpopulations of a composite cross population of barley, Cambridge $\mathrm{CCV}$, have evolved towards significantly higher resistance to powdery mildew caused by Erysiphe graminis f. sp. hordei.

\section{Materials and methods}

Plant material

Composite Cross Five (CCV) was developed between 1937 and 1940 by hierarchical crossing of 30 diverse accessions from the USDA collection of barley (Suneson, 1956). The bulked hybrid seeds were designated $F_{1}$ and subsequent generations have been grown at Davis, California since 1941. The material has been maintained as discrete generations in large populations, with no conscious selection (Jain \& Allard, 1960). In 1974, large samples of seed from the $F_{10}, F_{20}$ and $F_{30}$ generations of Californian 
CCV were used to establish three parallel populations in Cambridge, U.K. - Populations 1, 2 and 3 of Cambridge CCV, respectively (Luckett, 1982; Luckett \& Sharif, 1987; Ibrahim, 1989; Ibrahim \& Barrett, 1991).

The plant material used in this study consisted of the 100 family lines derived from each of the $F_{12}$, $F_{15}, \quad F_{18}$ and $F_{21}$ generations of Population 1, Cambridge $\mathrm{CCV}$, as described by Ibrahim \& Barrett (1991).

\section{Hordein extraction and separation}

Individual seeds were cut transversely and the part distal to the embryo was crushed using a pair of pliers the serrated jaws of which had been machined to a smooth surface. A single solvent mixture containing 2-mercaptoethanol, as described by Smith \& Payne (1984), was used to extract the endosperm proteins from the crushed sample. During the extraction, the proteins are reduced and denatured allowing individual subunits to be resolved by gel electrophoresis.

The polypeptide units were separated in 17.5 per cent acrylamide gels ( 3 per cent stacking gel) and stained with Coomassie Blue $\mathrm{R}$, as described by Smith \& Payne (1984). The number, width and migration distance of the different bands were scored on each gel. Following the convention of Shewry et al. (1978a,b), the band patterns of the B hordeins were given numbers and those of the $\mathrm{C}$ and $\mathrm{D}$ hordeins were assigned letter codes.

\section{Mildew resistance}

Reaction to natural infection from the air spora was scored on the parent plants from which the 400 family lines were derived; the plants were scored on a scale of 0 (highly resistant) to 5 (highly susceptible) (for details see Ibrahim \& Barrett, 1991) and regrouped into two categories 'resistant' $(0-2)$ and 'susceptible' (3-5) for analysis. In addition, seedlings from 99 family lines from the $F_{12}$ and $F_{21}$ generations were grown in a disease-free environment and tested for resistance to four mildew isolates with known virulence spectra (for details, see Ibrahim \& Barrett, 1991).

\section{Results}

\section{Hordeins}

The frequencies of the $\mathrm{B}$ and $\mathrm{C}$ hordein patterns (Table 1) show that there is a gradual decrease in
Table 1 Frequency of hordein band patterns in 400 family lines from four generations of barley Population 1, Cambridge CCV

\begin{tabular}{|c|c|c|c|c|c|}
\hline \multirow[b]{2}{*}{ Hordeins } & \multirow{2}{*}{$\begin{array}{l}\text { Pattern } \\
\text { code }\end{array}$} & \multicolumn{4}{|c|}{ Generations } \\
\hline & & $F_{12}$ & $F_{15}$ & $F_{18}$ & $F_{21}$ \\
\hline \multirow[t]{9}{*}{ B } & 1 & 31 & 25 & 22 & 19 \\
\hline & 2 & 28 & 9 & 7 & 5 \\
\hline & 3 & 5 & 7 & 3 & 5 \\
\hline & 4 & 8 & 12 & 7 & 3 \\
\hline & 5 & 11 & 17 & 1 & 3 \\
\hline & 6 & 8 & 19 & 53 & 59 \\
\hline & $7 \dagger$ & 3 & 1 & 0 & 0 \\
\hline & $8 \dagger$ & 3 & 2 & 5 & 1 \\
\hline & $9 \dagger$ & 3 & 8 & 2 & 5 \\
\hline \multirow[t]{8}{*}{$\mathrm{C}$} & A & 14 & 22 & 65 & 70 \\
\hline & A1 & 40 & 27 & 13 & 11 \\
\hline & B & 13 & 18 & 9 & 9 \\
\hline & B1 & 5 & 17 & 3 & 4 \\
\hline & C & 20 & 12 & 8 & 6 \\
\hline & $\mathrm{D} \dagger$ & 2 & 2 & 1 & 0 \\
\hline & $\mathrm{E} \dagger$ & 2 & 2 & 1 & 0 \\
\hline & $\mathrm{G}^{\dagger}$ & 4 & 0 & 0 & 0 \\
\hline \multirow[t]{2}{*}{$\mathrm{D}$} & $S$ & 95 & 84 & 94 & 95 \\
\hline & $\mathrm{F}$ & 5 & 16 & 6 & 5 \\
\hline
\end{tabular}

Tests of association between these hordein patterns and the four generations gave $\chi^{2}$ values of 111.28 (d.f. $=18$, $P<0.001$ ), 118.46 (d.f. $=15, P<0.001$ ) and 9.32 (d.f. $=3$, $0.01<P<0.05$ ) for $\mathrm{B}, \mathrm{C}$ and $\mathrm{D}$ hordeins, respectively (see Table $3 \mathrm{~b})$. $\dagger$ indicates the pattern classes that were pooled to avoid small expected values.

the frequency of all but one of the patterns of both hordein groups. For the B hordeins, pattern 6 has become the predominant type by $F_{18}$, although it was one of the least common patterns in $F_{12}$. Similarly, pattern $\mathrm{A}$ of the $\mathrm{C}$ hordeins which was present in 14 per cent of the lines in $\mathrm{F}_{12}$ marked 70 per cent of the lines in $F_{21}$. There is also a reduction in the total number of patterns in successive generations. Nine $B$ hordein patterns were detected in the $F_{12}$ and $F_{15}$ lines, whereas in $F_{18}$ and $F_{21}$ there were only eight. Similarly, eight, seven, seven and five distinct $\mathrm{C}$ hordein patterns were detected in the $F_{12}, F_{15}, F_{18}$ and $F_{21}$ lines, respectively. It is clear also that there has been a directional shift towards increased frequency of specific patterns of both hordein groups in successive generations. The two D hordein patterns, $\mathrm{S}$ and $\mathrm{F}$, showed frequency fluctuations in successive generations, but no directional trend was evident. 
$\mathrm{B}$ and $\mathrm{C}$ hordein pattern combinations might be expected to show a high level of association because of the tight linkage between their respective loci, Hor 2 and Horl. With nine and eight variants, respectively, the number of possible pattern combinations between the B and C hordeins is 72 . The actual number observed in the total sample (i.e. before pooling for analysis) was 36 . There were 28 ,
25, 19 and 15 distinct pattern combinations in $F_{12}$, $F_{15}, F_{18}$ and $F_{21}$, respectively, again clearly indicating a gradual loss of some genetic diversity. Table 2 shows the frequency of pattern combinations in successive generations after combining $\mathrm{B}$ and $\mathrm{C}$ hordein patterns present at less than 5 per cent into the pooled classes, 0 and $P$, respectively. This reduced the number of $\mathrm{B}$ and $\mathrm{C}$ hordein patterns to

Table 2 The frequency of hordein pattern combinations in four generations of Cambridge CCV of barley

\begin{tabular}{|c|c|c|c|c|c|c|}
\hline \multirow[b]{2}{*}{$\mathrm{B} / \mathrm{C}$ hordeins } & \multicolumn{4}{|c|}{ Generations } & \multicolumn{2}{|c|}{ Total } \\
\hline & $\mathrm{F}_{12}$ & $\mathrm{~F}_{15}$ & $\mathrm{~F}_{18}$ & $F_{21}$ & $\mathrm{R}$ & $S$ \\
\hline $1 / \mathrm{A}$ & 3 & 5 & 4 & 9 & 11 & 11 \\
\hline 1/A1 & 14 & 2 & 5 & 2 & 6 & 17 \\
\hline $1 / \mathrm{B}$ & 5 & 1 & 6 & 4 & 4 & 12 \\
\hline 1/B1 & 4 & 15 & 3 & 4 & 5 & 21 \\
\hline $1 / \mathrm{C}$ & 3 & 0 & 2 & 0 & 1 & 4 \\
\hline $1 / \mathrm{P}$ & 2 & 2 & 1 & 0 & 0 & 5 \\
\hline $2 / \mathrm{A}$ & 2 & 1 & 2 & 1 & 3 & 3 \\
\hline 2/A1 & 19 & 6 & 4 & 4 & 7 & 26 \\
\hline $2 / \mathrm{C}$ & 5 & 2 & 1 & 0 & 0 & 8 \\
\hline $2 / \mathrm{P}$ & 2 & 0 & 0 & 0 & 0 & 2 \\
\hline $3 / \mathrm{B}$ & 0 & 0 & 0 & 1 & 0 & 1 \\
\hline $3 / \mathrm{C}$ & 5 & 6 & 3 & 4 & 7 & 11 \\
\hline $3 / \mathrm{P}$ & 0 & 1 & 0 & 0 & 0 & 1 \\
\hline $4 / \mathrm{A}$ & 1 & 0 & 1 & 0 & 2 & 0 \\
\hline 4/A1 & 2 & 8 & 3 & 3 & 4 & 12 \\
\hline 4/B & 0 & 1 & 0 & 0 & 0 & 1 \\
\hline 4/B1 & 1 & 1 & 0 & 0 & 0 & 2 \\
\hline $4 / C$ & 2 & 2 & 2 & 0 & 1 & 5 \\
\hline $4 / \mathrm{P}$ & 2 & 0 & 1 & 0 & 1 & 2 \\
\hline $5 / \mathrm{A}$ & 0 & 3 & 0 & 0 & 2 & 1 \\
\hline 5/A1 & 2 & 4 & 0 & 1 & 3 & 4 \\
\hline $5 / \mathrm{B}$ & 5 & 8 & 1 & 0 & 1 & 13 \\
\hline $5 / \mathrm{C}$ & 4 & 2 & 0 & 2 & 1 & 7 \\
\hline $6 / \mathrm{A}$ & 5 & 13 & 53 & 59 & 109 & 21 \\
\hline 6/A1 & 2 & 4 & 0 & 0 & 3 & 3 \\
\hline $6 / \mathrm{B} 1$ & 0 & 1 & 0 & 0 & 0 & 1 \\
\hline $6 / \mathrm{C}$ & 1 & 0 & 0 & 0 & 0 & 1 \\
\hline 6/P & 0 & 1 & 0 & 0 & 0 & 1 \\
\hline $0 / \mathrm{A}$ & 3 & 0 & 4 & 1 & 4 & 4 \\
\hline $0 / \mathrm{A}$ & 1 & 3 & 1 & 1 & 1 & 5 \\
\hline $0 / \mathrm{B}$ & 3 & 8 & 2 & 4 & 4 & 13 \\
\hline $0 / \mathrm{P}$ & 2 & 0 & 0 & 0 & 0 & 2 \\
\hline No. of lines & 100 & 100 & 100 & 100 & 180 & 220 \\
\hline $\mathrm{B} / \mathrm{C}$ combinations & 26 & 24 & 19 & 15 & 21 & 31 \\
\hline$H^{\prime}$ (diversity) & 2.91 & 2.82 & 1.97 & 1.66 & 1.77 & 3.02 \\
\hline Maximum $H^{\prime}$ & 3.26 & 3.18 & 2.94 & 2.71 & 3.04 & 3.43 \\
\hline Rel. diversity & 0.89 & 0.89 & 0.67 & 0.61 & 0.58 & 0.88 \\
\hline
\end{tabular}

The Total columns show the patterns of the lines resistant $(\mathrm{R})$ or susceptible (S) to powdery mildew summed over all generations. Patterns ' 0 ' and 'P' are the pooled categories for the $\mathrm{B}$ and $\mathrm{C}$ hordeins, respectively. Relative diversity $=H^{\prime}$ /maximum $H^{\prime}$ (see text). 
seven and six, respectively, and hence there were 42 possible pattern combinations of which only 32 were detected in the total sample.

Six combinations (eight individuals) that were not present in $F_{12}$ were detected in the later generations. Five of these (seven individuals) were in $F_{15}$, whereas the remaining one was detected in the $F_{21}$ lines. These new combinations were all present at frequencies less than 5 per cent. It is possible that they were present in $F_{12}$ but were not detected because of the limited sample size. It is also possible that they originated from segregating families arising from residual heterozygosity (from the crossing stages) or the rare outcrossing (less than 1 per cent) reported in the Cambridge $\mathrm{CCV}$ populations (Luckett, 1982).

A crude indication of the relative decline in multilocus diversity can be shown using $H^{\prime}$, the ShannonWeaver diversity index (Shannon \& Weaver, 1964) which integrates the changes in the numbers of genotypes and their frequencies. For an infinite population, $H^{\prime}=-\Sigma p_{i} \ln p_{i}$ where $p_{i}$ is the frequency of genotype $i$; the bias in $H^{\prime}$ because of finite sample size is small enough to be ignored in most applications (Peet, 1974). Table 2 shows the values of $H^{\prime}$ and Relative Diversity $\left(=H^{\prime}\right.$ /maximum $H^{\prime}$ ) for each of the generations; maximum $H^{\prime}$ is estimated by $\ln N$ where $N$ is the number of genotypes. For consistency, both indices have been estimated using the pooled categories; the use of all genotypes, without pooling, makes little difference to either index. The decline in absolute and relative diversity in successive generations seen for each of the hordein loci is also evident in the pattern combinations.

There is also clear evidence of linkage disequilibrium between variants at the Hor1 and Hor2 loci. Single combinations of the two always account for more than 40 per cent of the lines showing a particular B pattern. For example, 67.35 per cent of all lines marked by B pattern 2 had the A1 pattern of the $C$ hordeins. Similarly $3 / C, 4 / A 1,5 / B$, $6 / \mathrm{A}$ and $0 / \mathrm{B}$ combinations accounted for 90 per cent, 53 per cent, 44 per cent, 94 per cent and 52 per cent of all the lines showing the respective $\mathrm{B}$ patterns. Pattern 1 of the $\mathrm{B}$ hordeins appears to have 'recombined' freely with four $C$ patterns, A, A1, B and B1. A striking aspect of the data in Table 2 is the marked increase in the frequency of the $6 \mathrm{~A}$ pattern combination in $\mathrm{F}_{18}$ and $F_{21}$ at the expense of nearly all other pattern combinations. The frequency of lines marked by the $6 \mathrm{~A}$ combination increased from 5 per cent in $F_{12}$ to 59 per cent in $\mathrm{F}_{21}$.

\section{Hordeins and mildew resistance}

The frequency changes observed in the hordein banding patterns of the successive generations of Cambridge $\mathrm{CCV}$ were comparable to those previously reported for reaction to powdery mildew (Ibrahim \& Barrett, 1991). Because both characters were studied on the same family lines, it was possible to test for association between them, and to investigate whether the shifts in hordein banding patterns represent a correlated response to selection for mildew resistance.

Table $3 \mathrm{a}$ lists the numbers of the family lines which showed the different hordein banding patterns and their reaction to natural infection. Patterns occurring at frequencies less than 5 per cent were pooled, as described above. Taking each hordein locus in turn, the data were analysed as threedimensional contingency tables, following the procedures for log-linear models described by Bishop et al. (1975) and Sokal \& Rohlf (1981). To avoid problems with cells containing zero, 0.5 was added to all cell entries before analysis. The sequence of fitting in each case was to test for the three-way interaction $($ Generations $(\mathrm{G}) \times$ Disease Reaction $(\mathrm{R}) \times$ Hordein Pattern (P)) and then to remove sequentially the two-way interactions for Hordein Pattern $\times$ Disease Reaction, Hordein Pattern $\times$ Generations and finally Disease Reaction $\times$ Generations (see Table $3 b$ ). Analyses of five-way $(\operatorname{Hor} B \times \operatorname{HorC} \times \operatorname{HorD} \times$ Disease Reaction $\times$ Generations) and four-way (omitting HorD) tables were not justified because of the small number of observed three-locus and two-locus genotype combinations, relative to the possible number of combinations (see previous section and Table 2). To reduce the chances of Type I error, tests yielding probability values greater than 1 per cent were considered to be 'not significant'. There was no three-way interaction for any of the three loci, indicating that the form of association between disease reaction and hordein phenotype does not vary among generations. In the case of the $\mathrm{B}$ and $\mathrm{C}$ hordeins, all two-way interactions were highly significant. These indicate that both disease reaction and hordein pattern frequencies were, individually, changing with time and that there was a strong association between disease reaction and hordein pattern at these two loci. In the case of the D hordeins, the only strong effect was the change in disease reaction with time, which is to be expected because the data for disease reaction in each generation are the same for all three loci.

In the total sample of 400 family lines, 180 were resistant to natural infection, and, of these, $112(62.2$ 
Table 3a The hordein banding pattern and the reaction to natural infection $(R=$ resistant, $S=$ susceptible $)$ of the 400 family lines from the four generations of barley Population 1, Cambridge CCV

\begin{tabular}{|c|c|c|c|c|c|c|c|c|c|c|}
\hline \multirow{3}{*}{$\begin{array}{l}\text { Band } \\
\text { pattern }\end{array}$} & \multicolumn{8}{|c|}{ Generation } & & \\
\hline & \multicolumn{2}{|c|}{$\mathrm{F}_{12}$} & \multicolumn{2}{|c|}{$F_{15}$} & \multicolumn{2}{|c|}{$\mathrm{F}_{18}$} & \multicolumn{2}{|c|}{$\mathrm{F}_{21}$} & \multicolumn{2}{|c|}{ Total } \\
\hline & $\mathrm{R}$ & $\mathrm{S}$ & $\mathrm{R}$ & $\mathrm{S}$ & $\mathrm{R}$ & $\mathrm{S}$ & $\mathrm{R}$ & $\mathrm{S}$ & $\mathrm{R}$ & $\mathrm{S}$ \\
\hline \multicolumn{11}{|c|}{ B hordeins } \\
\hline 1 & 5 & 26 & 2 & 23 & 7 & 15 & 13 & 6 & 27 & 70 \\
\hline 2 & 6 & 22 & 0 & 9 & 1 & 6 & 3 & 2 & 10 & 39 \\
\hline 3 & 2 & 3 & 1 & 6 & 1 & 2 & 3 & 2 & 7 & 13 \\
\hline 4 & 3 & 5 & 1 & 11 & 2 & 5 & 2 & 1 & 8 & 22 \\
\hline 5 & 2 & 9 & 3 & 14 & 0 & 1 & 2 & 1 & 7 & 25 \\
\hline 6 & 4 & 4 & 10 & 9 & 49 & 4 & 49 & 10 & 112 & 27 \\
\hline 0 & 0 & 9 & 0 & 11 & 5 & 2 & 4 & 2 & 9 & 24 \\
\hline \multicolumn{11}{|c|}{$\mathrm{C}$ hordeins } \\
\hline A & 7 & 7 & 11 & 11 & 56 & 9 & 57 & 13 & 131 & 40 \\
\hline A1 & 10 & 30 & 5 & 22 & 3 & 10 & 6 & 5 & 24 & 67 \\
\hline B & 1 & 12 & 0 & 18 & 2 & 7 & 6 & 3 & 9 & 40 \\
\hline B1 & 0 & 5 & 0 & 17 & 2 & 1 & 3 & 1 & 5 & 24 \\
\hline $\mathrm{C}$ & 3 & 17 & 1 & 11 & 2 & 6 & 4 & 2 & 10 & 36 \\
\hline $\mathrm{P}$ & 1 & 7 & 0 & 4 & 0 & 2 & 0 & 0 & 1 & 13 \\
\hline \multicolumn{11}{|c|}{ D hordeins } \\
\hline F & 0 & 5 & 0 & 16 & 3 & 3 & 4 & 1 & 7 & 25 \\
\hline$S$ & 22 & 73 & 17 & 67 & 62 & 32 & 72 & 23 & 173 & 195 \\
\hline Total & 22 & 78 & 17 & 83 & 65 & 35 & 76 & 24 & 180 & 220 \\
\hline
\end{tabular}

Table 3b Summary of the fully hierarchical log-linear analyses for independence of pattern $(P)$, disease reaction $(R)$ and generations $(\mathrm{G})$ for each hordein type (data from Table $3(\mathrm{a})$ )

\begin{tabular}{|c|c|c|c|c|c|c|}
\hline \multirow[b]{2}{*}{$\begin{array}{l}\text { Interaction term removed and } \\
\text { (goodness-of-fit) after removal }\end{array}$} & \multicolumn{2}{|c|}{$\begin{array}{l}\text { B hordein } \\
\text { pattern }\end{array}$} & \multicolumn{2}{|c|}{$\begin{array}{l}\mathrm{C} \text { hordein } \\
\text { pattern }\end{array}$} & \multicolumn{2}{|c|}{$\begin{array}{l}\mathrm{D} \text { hordein } \\
\text { pattern }\end{array}$} \\
\hline & d.f. & $\chi^{2}$ & d.f. & $\chi^{2}$ & d.f. & $\chi^{2}$ \\
\hline $\begin{array}{l}\text { Pattern } \times \text { reaction } \times \text { generations } \\
\text { (Goodness-of-fit) }\end{array}$ & 18 & $20.41 \mathrm{NS}$ & 15 & $16.02 \mathrm{NS}$ & 3 & $2.09 \mathrm{NS}$ \\
\hline $\begin{array}{l}\text { Pattern } \times \text { reaction } \\
\text { (Goodness-of-fit) } \\
\text { independence of } P \text { and } R \text { at each } \\
\quad \text { level of } G\end{array}$ & $\begin{array}{r}6 \\
(24\end{array}$ & $\begin{array}{l}55.22^{* * *} \\
\left.75.63^{* * *}\right)\end{array}$ & $\begin{array}{r}5 \\
(20\end{array}$ & $\begin{array}{l}57.07^{* * *} \\
\left.73.08^{* * *}\right)\end{array}$ & $\begin{array}{r}1 \\
(4\end{array}$ & $\begin{array}{l}3.61 \mathrm{NS} \\
5.70 \mathrm{NS})\end{array}$ \\
\hline $\begin{array}{l}\text { Pattern } \times \text { generations } \\
\text { (Goodness-of-fit) } \\
\text { independence of } G \text { and combinations } \\
\text { of } P \text { and } R\end{array}$ & $\begin{array}{r}18 \\
(42\end{array}$ & $\begin{array}{l}111.28^{* * *} \\
\left.186.91^{* *}\right)\end{array}$ & $\begin{array}{r}15 \\
(35\end{array}$ & $\begin{array}{l}118.46^{* * *} \\
\left.191.54^{* * *}\right)\end{array}$ & $\begin{array}{r}3 \\
(7\end{array}$ & $\begin{array}{c}9.32^{*} \\
\left.15.02^{*}\right)\end{array}$ \\
\hline $\begin{array}{l}\text { Reaction } \times \text { generations } \\
\text { (Goodness-of-fit) } \\
\quad \text { complete independence }\end{array}$ & $\begin{array}{r}3 \\
(45\end{array}$ & $\begin{array}{l}105.76^{* * *} \\
\left.292.68^{* * *}\right)\end{array}$ & $\begin{array}{r}3 \\
(38\end{array}$ & $\begin{array}{l}106.89^{* * *} \\
\left.298.43^{* * *}\right)\end{array}$ & $\begin{array}{r}3 \\
(10\end{array}$ & $\begin{array}{l}111.68^{* * *} \\
\left.126.69^{* * *}\right)\end{array}$ \\
\hline
\end{tabular}


per cent) showed B pattern number six. These make up 80.6 per cent of all of the lines that had this pattern. Pattern A of the $\mathrm{C}$ hordeins marked 72.8 per cent of the resistant lines and these accounted for 76.6 per cent of the lines showing this pattern. Among D hordein patterns nearly all resistant lines (96.1 per cent) appeared to have the slow band (S), but a substantial proportion of the susceptible plants (88.6 per cent) also showed this pattern.

We have already shown that the number of $B / C$ pattern combinations detected decreased in successive generations. The distribution of pattern combinations in the mildew reaction classes provides an explanation for the reduction of diversity over generations (Table 2). There were 21 pattern combinations in the resistant lines, the most frequent being 6/A which accounted for 60.6 per cent of the resistant lines. The second most common pattern combination was $1 / \mathrm{A}$ and it accounted for only 6.1 per cent of the resistant lines. In contrast, 31 of the 32 pattern combinations detected in the total sample were present in the susceptible lines; the most frequent pattern in this class, 2/A1 accounted for only 11.8 per cent of the lines. Hence selection for resistance to powdery mildew may have led to a reduction in diversity of pattern combinations among resistant lines. This is supported by the observation that the hordein pattern diversity in the susceptible lines, as measured by the ShannonWeaver index, was higher than the diversity in the resistant lines (Table 2).

The fully hierarchical log-linear analyses of the results for the tests of 99 family lines against four powdery mildew isolates with known virulence spectra were carried out separately for each hordein locus. There was a highly significant three-way interaction between hordein pattern, mildew isolate and disease reaction in the analyses of the $\mathrm{B}$ hordeins $\left(\chi_{9}^{2}=63.79^{* * *}\right)$ and $\mathrm{C}$ hordeins $\left(\chi_{9}^{2}=40.52^{* * *}\right)$ but not for the D hordein patterns $\left(\chi_{3}^{2}=1.59 \mathrm{NS}\right)$; application of Williams's Correction (Williams, 1976) on the significant three-way interactions did not remove the significance (B hordein patterns, $\chi_{9}^{2}=56.64^{* * *}$; $\mathrm{C}$ hordein patterns, $\left.\chi_{9}^{2}=35.72^{* * *}\right)$. This implies that the degree of association between these hordein patterns and disease reaction differs for different isolates. In this case, tests of association between hordein phenotype and mildew reaction are only useful within each mildew isolate level (these tests are shown in Table 4). For the D hordeins, the test for a three-way interaction was not significant $\left(\chi_{1}^{2}=1.59 \mathrm{NS}\right)$. However, there were highly significant two-way interactions between hordein pattern and disease reaction $\left(\chi_{1}^{2}=17.09\right.$; see also Table 4$)$ and, as might be expected, between mildew isolate and disease reaction $\left(\chi_{3}^{2}=39.60\right)$.

Reactions to isolates $\mathrm{CC} / 1, \mathrm{CC} / 99$ and $\mathrm{CC} / 128$ were found to be significantly associated with the $\mathrm{B}$ and $\mathrm{C}$ hordein pattern variants, whereas $\mathrm{D}$ patterns only showed a significant association in their reaction to $\mathrm{CC} / 1$ (Table 4). Reaction to the fourth isolate $\mathrm{CC} / 124$, which did not vary between generations (Ibrahim \& Barrett, 1991), showed no significant association with the hordein variants (Table 4). Where significant association between reaction to mildew isolates and hordein variants was present, the pattern was similar to that observed between the reaction to natural infection and hordein patterns. Pattern 6 of $\mathrm{B}$ hordein and pattern $\mathrm{A}$ of $\mathrm{C}$ hordein were by far the most common in the lines resistant to the three isolates $\mathrm{CC} / 1, \mathrm{CC} / 99$ and CC/128 (Table 4).

\section{Discussion}

Repeated tests of the family lines have shown that the different $\mathrm{B}$ and $\mathrm{C}$ hordein patterns are both replicable and distinct from one another. Nevertheless, two-dimensional electrophoresis has shown that differences may exist between patterns which are apparently identical when using one-dimensional electrophoresis (Shewry et al., 1978b). Hence, the separation procedure adopted here may not have resolved all of the pattern variants, and 'identical' band patterns may not be the product of the same allele. The data presented therefore provide a conservative estimate of the level of polymorphism at the three hordein loci.

Because of the tight linkage between the Horl and Hor 2 loci, linkage equilibrium between these two loci may not have been achieved during the initial crossing phase, and, because of the inbreeding nature of barley, any initial linkage disequilibrium will persist in the absence of selection. In the presence of selection on one or both of these loci, or on a locus (or loci) with which they are also in linkage disequilibrium, the initial linkage disequilibrium will change over the generations because of the hitch-hiking effect. The frequency shifts of the patterns at each locus, individually, and of the multilocus combinations suggest that selection has favoured certain alleles at one or both of these loci, or other loci in linkage disequilibrium with the Horl and Hor 2 loci. The $6 \mathrm{~A}$ pattern combination, in particular, appears to have marked plants that have been favoured by selection.

When the genetic composition of populations of inbreeding species shows consistent directional 
Table 4 The hordein banding patterns and reaction to four mildew isolates ( $R=$ resistant, $S=$ susceptible) of 99 family lines derived from $F_{12}$ and $F_{21}$ of barley Population 1, Cambridge CCV

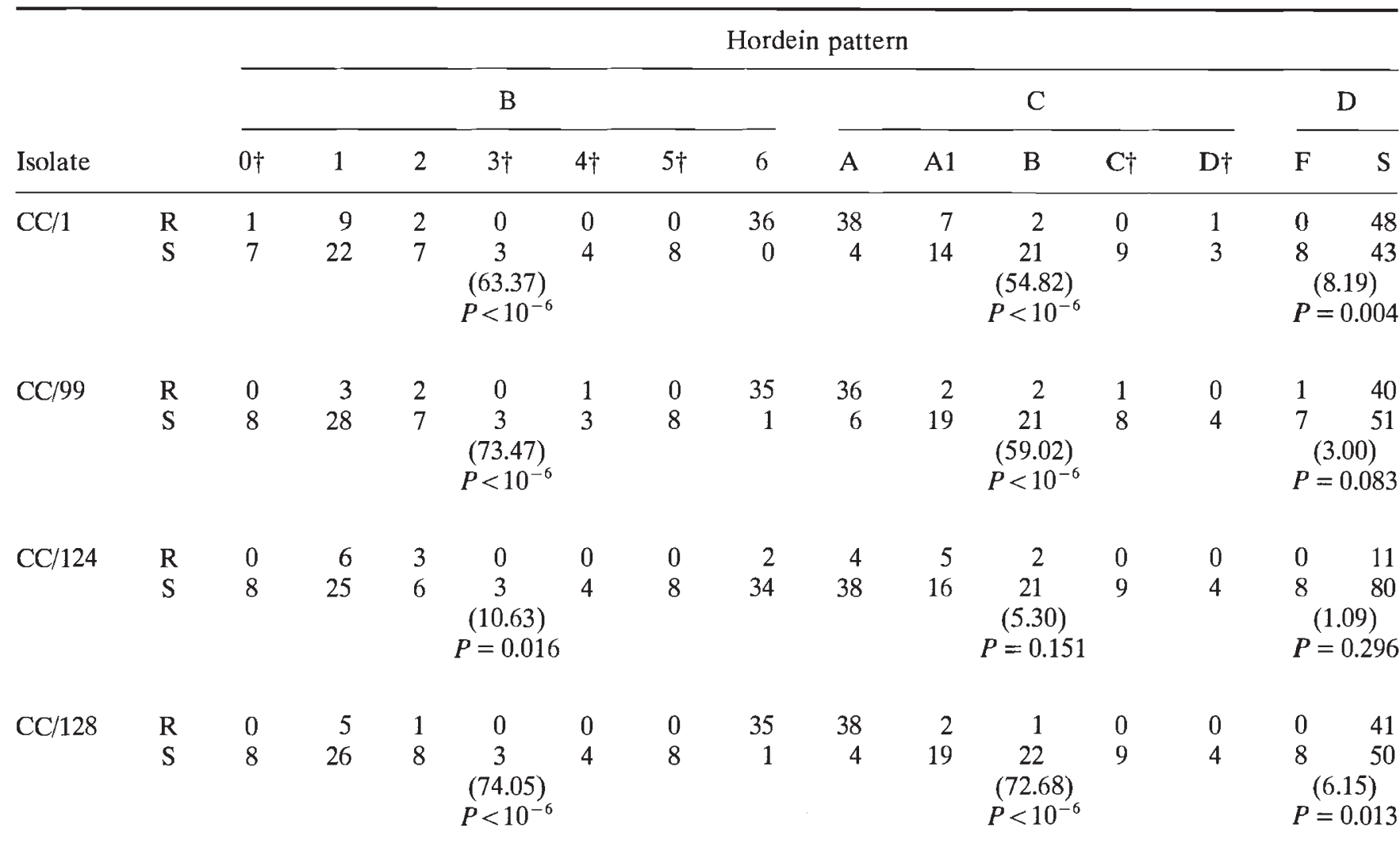

Figures in brackets for each subtable are the $\chi^{2}$ values for tests of association between the patterns at individual hordein loci and their reaction to each isolate; d.f. $=3$ for all tests involving B hordeins and $\mathrm{C}$ hordeins and d.f. $=1$ for all tests involving D hordeins. Columns marked with $\dagger$ indicate patterns that were pooled at each locus to avoid small expected values.

change over time because of natural selection, it is difficult to identify a particular character as the target of selection. In a previous study (Ibrahim \& Barrett, 1991), we have argued that natural infection by mildew could be a major selective force responsible for the changes observed in Cambridge CCV. Here we argue that the linkage between some hordein and mildew resistance loci (Jensen et al., 1980; Shewry et al., 1981) could have led to directional changes in the frequencies of alleles at the hordein loci.

In spite of the magnitude of the shifts favouring particular genotypes, a substantial amount of genetic variation is still retained in Cambridge CCV. This is evident from the fact that, despite the limited sample size, we were able to detect in $F_{21}$ all but four rare patterns (frequency less than 5 per cent in $F_{12}$ ) of the 19 band patterns observed in $F_{12}$ (Table $1)$. The mean expected panmictic heterozygosity
$\left(H_{\mathrm{e}}=\Sigma p_{i}\left(1-p_{i}\right)\right.$ where $p_{i}$ is the frequency of the $i$ th allele) averaged over the three hordein loci was $0.5497,0.6364,0.4383$ and 0.3953 in $F_{12}, F_{15}, F_{18}$ and $\mathrm{F}_{21}$, respectively (Brown, 1978; Asins \& Carbonell, 1987); this indicates that genetic diversity at the hordein loci has not been seriously eroded when measured on a per-locus basis.

However, in terms of multilocus genotypes in the population, there has been a demonstrable decline in genetic diversity over 10 generations (Table 2). Although it seems reasonably obvious that bulk populations can have a role in genetic conservation (Ford-Lloyd \& Jackson, 1986; Allard, 1990), different strategies might have to be adopted in the case of inbreeding species, like barley, depending on whether the objective is to conserve multilocus genetic structure or genetic diversity locus-by-locus. This is because linkage disequilibria caused by both drift and selection will lead to a higher rate of loss 
for multilocus genotypes than for alleles at individual loci.

\section{Acknowledgements}

We wish to thank Professor M. S. Wolfe for providing laboratory facilities and guidance for the mildew isolate tests, and $\mathrm{Mr}$ John Spencer for technical assistance and helpful discussions.

\section{References}

ALLARD, R. W. 1988. Genetic changes associated with the evolution of adaptedness in cultivated plants and their wild progenitors. J. Hered., 79, 225-238.

ALLARD, R. w. 1990. The genetics of host-pathogen co-evolution: Implications for genetic resource conservation. J. Hered., 81, 1-6.

Allard, R. W., KAHLER, A. L. AND WeIR, B. S. 1972. The effect of selection on esterase allozymes in a barley population. Genetics, 72, 489-503.

ASINS, M. J. AND CARBonell, E. A. 1987. Concepts involved in measuring genetic variability and its importance in conservation of plant genetic resources. Evol. Trends Plants, 1, 51-62.

BISHOP, Y. M. M., FIENBERG, S. E. AND HOLLAND, P. W. 1975. Discrete Multivariate Analysis: Theory and Practice. MIT Press, Cambridge, MA.

BRown, A. H. D. 1978. Isozymes, plant population genetic structure and genetic conservation. Theor. Appl. Genet., 52, 145-157.

ClegG, M. T., KAHLER, A. L AND Allard, R. W.. 1978. Estimation of life cycle components of selection in an experimental plant population. Genetics, 89, 765-792.

DOLL, H. AND BROWN, A. H. D. 1979. Hordein variation in wild (Hordeum spontaneum) and cultivated (Hordeum vulgare) barley. Can. J. Genet. Cytol., 21, 391-404.

EDWARDS, K. J. R. 1975. Natural selection and biochemical properties of polymorphic esterases in barley. In: Proceedings of the Third International Barley Genetics Symposium, pp. 23-29. Graching, Federal Republic of Germany.

FIELD, J. M., SHEWRY, P. R., MIFLIN, B. J. AND MARCH, J. F. 1982. The purification and characterization of homologous high molecular weight storage proteins from the grain of wheat rye and barley. Theor. Appl. Genet., 62, 329--336.

FORD-Lloyd, B. AND JACKSON, M. 1986. Plant Genetic Resources: An Introduction to Their Conservation and Use. Edward Arnold, London.

ibrahim, к. M. 1989. Genetic Variation in Composite Cross Five of Barley. Ph.D. Thesis, University of Cambridge.

IBRAHIM, K. M. AND BARRETT, J. A. 1991. Evolution of mildew resistance in a hybrid bulk population of barley. Heredity, 67, 247-256.

JAIN, S. K. AND ALLARD, R. W. 1960. Population studies in predominantly self-pollinated species. I: Evidence for heterozygote advantage in a closed population of barley. Proc. Natl. Acad. Sci. U.S.A., 46, 1371-1377.

JENSEN, J., JøRGENSEN, J. H., JENSEN, H., GIESE, H. AND DOLL, H. 1980. Linkage of the hordein loci Horl and Hor 2 with the powdery mildew resistance loci $M l-k$ and Ml-a on barley chromosome V. Theor. Appl. Genet., 58, 27-31.

JøRGENSEN, J. H. 1994. Genetics of powdery mildew resistance in barley. Crit. Rev. Plant Sci., 13, 97-119.

KAHLER, A. L., ClEGG, M. T. AND ALlARD, R. W. 1975. Evolutionary changes in the mating system of an experimental population of barley (Hordeum vulgare L.). Proc. Natl. Acad. Sci. U.S.A., 72, 943-946.

KNIGHT, s. C. 1991. Genetic Variation in Composite Cross XLII of Barley. Ph.D. Thesis, University of Cambridge.

KREIS, M., SHEWRY, P. R., FORDE, B. G., FORDE, J. AND MIFLIN, B. J. 1985. Structure and evolution of seed storage proteins and their genes with particular reference to those of wheat, barley and rye. In: Miflin, B. J. (ed.) Oxford Surveys of Plant Molecular and Cell Biology, vol. 2, pp. 253-317, Oxford University Press, Oxford.

LUCKETT, D. J. 1982. Natural Selection in a Genetically Heterogeneous Population of Barley. Ph.D. Thesis, University of Cambridge.

LUCKETT, D. J. AND EDWARDS, K. J. R. 1986. Esterase genes in parallel composite cross barley populations. Genetics, 114, 289-302.

LUCKETT, D. J. AND SHARIF, A. L. 1987. Metrical characters in parallel-grown subpopulations of barley composite cross five. Aust. J. Biol. Sci., 40, 65-77.

PEET, R. K. 1974. The measurement of species diversity. Ann. Rev. Ecol. Syst., 5, 285-307.

SHANNON, C. E. AND WEAVER, w. 1964. The Mathematical Theory of Communication. The University of Illinois Press, Urbana.

SHEWRY, P. R., Ellis, J. R. S., PRATT, H. M. AND MIFLIN, B. J. 1978a. Varietal identification of single seeds of barley by analysis of hordein polypeptides. J. Sci. Food Agric., 29, 587-596.

SHEWRY, P. R., ELliS, J. R. S., PRATT, H. M. AND MIFLIN, B. J. 1978b. A comparison of methods for the extraction and separation of hordein fractions from 29 barley varieties. J. Sci. Food Agric., 29, 433-442.

SHEWRY, P. R., WOLFE, M. S., SLATER, S. E., PARMAR, S. R., FAUlKS, A. J. AND MifLiN, B. J. 1981. Barley storage proteins in relation to varietal identification, malting quality and mildew resistance. In: Barley Genetics IV, Proceedings of the Fourth International Barley Genetics Symposium, pp. 596-603. Edinburgh.

SHEWRY, P. R., FIELD, J. M., PARMAR, S. AND MIFLIN, B. J. 1982. 'D' Hordein, a new group of storage proteins in barley. Barley Genetics Newsletter, 12, 28-29.

SHEWRY, P. R., FINCH, R. A., PARMAR, S., FRANKLIN, J. AND MIFlin, B. J. 1983. Chromosomal location of Hor 3, a new locus governing storage proteins in barley. Heredity, 50, 179-189.

SHEWRY, P. R., MIFLIN, B. J. AND KASARDA, D. D. 1984. The structural and evolutionary relationships of the prola- 
min storage proteins of barley, rye and wheat. Phil. Trans. R. Soc. B, 304, 297-308.

SMITH, D. B. AND PAYNE, P. I. 1984. A procedure for the routine determination of electrophoretic band patterns of barley and malt endosperm proteins. J. Natl. Inst. Agric. Bot., 16, 487-498.

SOKAL, R. R. AND RoHlF, F. J. 1981. Biometry, 2nd edn. W. H. Freeman and Company, San Francisco.

SUNESON, C. A. 1956. An evolutionary plant breeding method. J. Agron., 48, 188-191.

WEIR, B. S., ALlARD, R. W. AND KAHLER, A. L. 1972. Analysis of complex allozyme polymorphisms in a barley population. Genetics, 72, 505-523.

WEIR, B. S., Allard, R. W. AND KAHLER, A. L. 1974. Further analysis of complex allozyme polymorphisms in a barley population. Genetics, 78, 911-919.

WILLIAMS, D. A. 1976. Improved likelihood ratio tests for complete contingency tables. Biometrika, 63, 33-37. 